\title{
Discovery of an orangeite magmatic event in the central Kalahari: Implications for the origin of southern African kimberlites
}

\author{
Marylou Vinès ${ }^{1}$, Sebastian Tappe ${ }^{1, *}$, Andreas Stracke ${ }^{2}$, Allan Wilson ${ }^{3}$, Andrew Rogers ${ }^{4}$ \\ ${ }^{1}$ University of Johannesburg, South Africa, *sebastiant@uj.ac.za \\ ${ }^{2}$ Westfälische Wilhelms-Universität Münster, Germany, stracke.andreas@uni-muenster.de \\ ${ }^{3}$ University of the Witwatersrand, South Africa, allan.wilson@wits.ac.za \\ ${ }^{4}$ Petra Diamonds South Africa (Pty) Ltd, andrew.rogers@petradiamonds.com
}

\section{Introduction}

Southern Africa hosts more than 1,600 kimberlite bodies, and over $75 \%$ of these fall within a 250 to $50 \mathrm{Ma}$ age range. These Mesozoic-Cenozoic kimberlites have Group-1 and Group-2 compositional affinities, with occurrences of both groups providing significant primary diamond deposits. While Group-1 kimberlites represent a relatively homogenous type of $\mathrm{CO}_{2}-$ and $\mathrm{H}_{2} \mathrm{O}$-rich ultramafic magma in cratonic regions worldwide (Kjarsgaard et al., 2009), Group-2 kimberlites are compositionally more diverse potassic rocks that are confined to the Kaapvaal craton with emplacement ages between 200-110 Ma (Mitchell, 1995). Most models proposed for the origin of Group-1 kimberlites suggest sublithospheric depleted upper mantle sources (Tappe et al., 2017), whereas the compositions of Group-2 kimberlites require long-term enriched sources (Smith et al., 1985; Becker and Le Roex, 2006), with cratonic mantle lithosphere providing a suitable substrate to generate these $\mathrm{H}_{2} \mathrm{O}$-rich potassic magmas. The complexity of Group-2 kimberlites is consistent with the heterogeneous nature of the Kaapvaal craton root (Giuliani et al., 2015), and some authors emphasized strong petrogenetic links to olivine lamproites and ultramafic lamprophyres from cratons worldwide (Tappe et al., 2008). Group-2 kimberlites may therefore be interpreted as the magmatic expression of metasomatized mantle lithosphere beneath the Kaapvaal craton. Within such a model each craton produces its own compositional 'flavour' of ultramafic potassic magmatism due to the differences in composition, style, and timing of lithospheric mantle enrichment. The re-introduction of the term 'orangeite' for Group-2 kimberlite (Mitchell, 1995) reinforced the fact that these often diamond-bearing rocks differ significantly from archetypal kimberlites and, thus, they should be treated separately within models that seek to explain volatile-rich mantle-derived magmatism on thick continental shields.

\section{KX36 Pipe - a newly discovered kimberlite occurrence in the central Kalahari of Botswana}

The KX36 kimberlite pipe was discovered in 2008 during geophysical surveying of the central Kalahari in Botswana (Rogers et al., 2013). The pipe represents a $\sim 5$ ha large magmatic body that is covered by $80 \mathrm{~m}$ of Kalahari Group sedimentary overburden. The KX36 kimberlite pipe cuts through $400 \mathrm{~m}$ of Karoo Supergroup basaltic lava, and the kimberlite magma has locally entrained up to 10-20 vol\% of basalt wall-rock, as well as some minor granitoid basement. On the basis of stratigraphy, the KX36 kimberlite pipe was emplaced between 180 and 50 Ma. The nearest known kimberlite occurrences are the Gope cluster some $60 \mathrm{~km}$ to the NW and the highly economic Orapa field some $250 \mathrm{~km}$ to the NNE of KX36, with kimberlite pipe emplacement ages between 115 and $80 \mathrm{Ma}$ (Griffin et al., 2014). However, our first U/Pb perovskite age results for two magmatic kimberlite units within the KX36 pipe indicate magma emplacement at the NW margin of the Kaapvaal craton between 160 and 140 Ma. The robustness of these preliminary results is currently tested by additional analyses, also including an alternative analytical method.

\section{Petrography and mineralogy}

Two main units, 'black' and 'green' kimberlite, can be distinguished within the KX36 pipe down to $\sim 500 \mathrm{~m}$ depth. Both units represent coherent magmatic kimberlite, and the green variety appears to be a hydrothermally altered and more crustally contaminated variant of the fresh black kimberlite. The black kimberlite is highly macrocrystic with individual olivine crystals approaching $15 \mathrm{~mm}$ across (up 
to $30 \mathrm{vol} \%$ ). Phlogopite macrocrysts up to $3 \mathrm{~mm}$ across are common (up to $5 \mathrm{vol} \%$ ). Their rims typically enclose minute groundmass spinel crystals. The groundmass of the black kimberlite variety consists of variable proportions of phlogopite flakes $(20-120 \mu \mathrm{m})$, carbonate and serpentine. Accessory groundmass phases comprise atoll-textured spinel and perovskite $(<60 \mu \mathrm{m})$, and very rare Mg-rich ilmenite.

A sizable $(20 \mathrm{~cm}$ across $)$ micaceous autolith was recovered from KX36 kimberlite drill core. The fresh autolith is inequigranular and dominated by olivine, phlogopite and clinopyroxene, with minor spinel, Mn-rich ilmenite, calcite, serpentine, apatite and Ti-rich andradite garnet. Macrocrystic olivine has high forsterite content of $\mathrm{Fo}_{92}$. Phlogopite has high $\mathrm{TiO}_{2}$ content $(1-4 \mathrm{wt} \%)$ and evolves by $\mathrm{Al}-$ depletion toward tetraferriphlogopite. Clinopyroxene is close to diopside end-member composition with minor amounts of Ti and Al. Spinel crystals occur in interstices and as inclusions in phlogopite and clinopyroxene. They have magnesian chromite composition with high $\mathrm{Cr} \#$ of up to 93 and low $\mathrm{TiO}_{2}$ content $(<6 \mathrm{wt} \%)$. Interstitial magmatic garnet has Ti-andradite composition with up to $1 \mathrm{wt} \%$ $\mathrm{ZrO}_{2}$. These mineralogical features suggest that the parent magma was of orangeite affinity.

\section{Bulk rock major- and trace element compositions}

Although the fresh black kimberlite variety of the KX36 pipe macroscopically resembles archetypal kimberlite, several mineralogical and geochemical features suggest a petrogenetic affinity to Group-2 kimberlite. For example, the transitional nature of the KX36 kimberlite between archetypal kimberlite and orangeite is illustrated by the elevated $\mathrm{K}$ contents at constant and low Ti concentration levels. This trend culminates at the micaceous autolith (Fig.1). Primitive mantle normalized incompatible element patterns show a significant slope for the LILE ( $\mathrm{Cs}, \mathrm{Rb}, \mathrm{Ba}$ ), unfractionated low concentrations for the HFSE (Th, U, Nb, Ta), and highly fractionated LREE/HREE. These patterns strongly resemble the trace element distributions of orangeites (Fig.2). The trace element pattern of the micaceous autolith is highly fractionated and bears resemblance to primitive continental arc volcanic rocks. Such a geochemical signature is typically found in subduction zone settings.

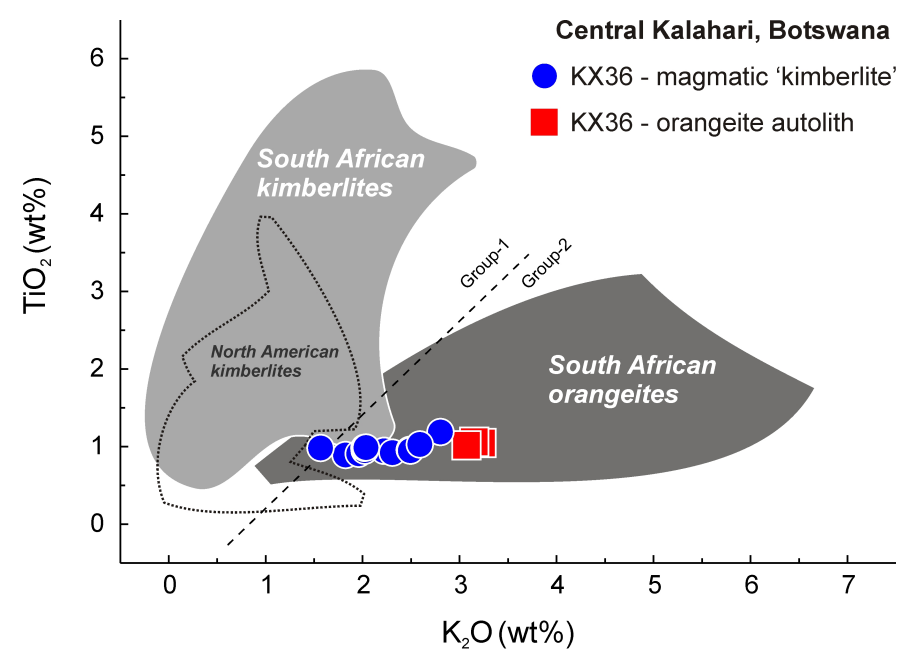

Figure 1: $\mathrm{TiO}_{2}$ vs. $\mathrm{K}_{2} \mathrm{O}$ for fresh uncontaminated (C.I. <1.25) magmatic KX36 kimberlite and an entrained micaceous autolith (fields for comparison from: Smith et al., 1985; Becker and Le Roex, 2006; Coe et al., 2008; Tappe et al., 2017).

\section{Preliminary conclusion}

Our study provides first evidence for the occurrence of kimberlite magmatism of Group-2 affinity in the central Kalahari basin. This discovery increases the geographic extent of ultramafic potassic magmatism in southern Africa by more than $300 \mathrm{~km}$ toward the NW Kaapvaal craton edge. As previously suggested for orangeite magmatism in other parts of the Kaapvaal craton (cf., Coe et al., 2008), the combination of a high-LILE and low-HFSE geochemical fingerprint at the NW craton margin is best explained by involvement of strongly K-metasomatized mantle lithosphere. The distinctive trace element signature can be linked to prior subduction-driven collision events during the Proterozoic evolution of the Kaapvaal craton and surrounding orogenic belts. 


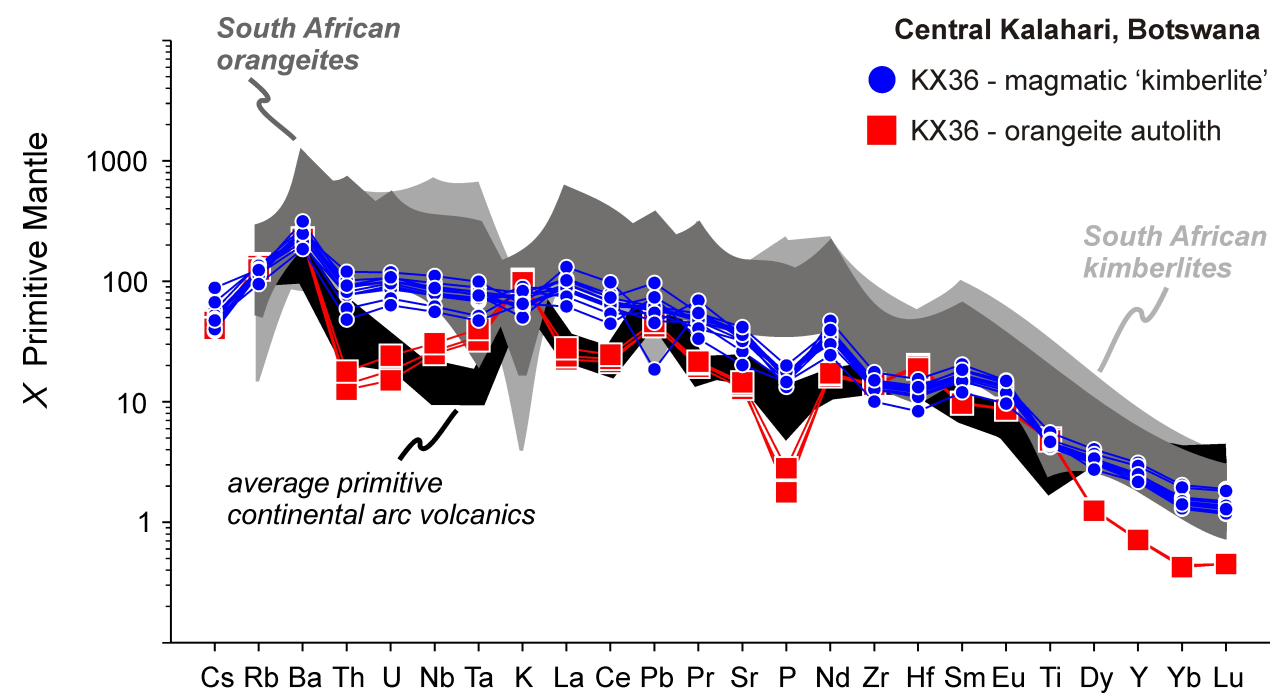

Figure 2: Normalized incompatible element patterns for fresh uncontaminated (C.I. <1.25) magmatic KX36 kimberlite and an entrained micaceous autolith (fields for comparison from: Becker and Le Roex, 2006; http://georoc.mpch-mainz.gwdg.de/georoc/).

\section{Acknowledgments}

This PhD study is conducted with support of the CIMERA DST-NRF Centre of Excellence at the University of Johannesburg. We thank 11-IKC for financial support to present this work at the conference.

\section{References}

Becker M, Le Roex AP (2006) Geochemistry of South African on- and off-craton, Group I and Group II kimberlites: Petrogenesis and source region evolution. J Petrol 47: 673-703

Coe N, Le Roex AP, Gurney JJ, Pearson DG, Nowell GM (2008) Petrogenesis of the Swartruggens and Star Group II kimberlite dyke swarms, South Africa: Constraints from whole rock geochemistry. Contrib Mineral Petrol 156: 627-652

Giuliani A, Phillips D, Woodhead JD, Kamenetsky VS, Fiorentini ML, Maas R, Soltys A, Armstrong RA (2015) Did diamond-bearing orangeites originate from MARID-veined peridotites in the lithospheric mantle? Nat Commun 6: 1-10

Griffin WL, Batumike JM, Greau Y, Pearson NJ, Shee SR, O'Reilly SY (2014) Emplacement ages and sources of kimberlites and related rocks in southern Africa: U-Pb ages and $\mathrm{Sr}-\mathrm{Nd}$ isotopes of groundmass perovskite. Contrib Mineral Petrol 168: 1-13

Kjarsgaard BA, Pearson DG, Tappe S, Nowell GM, Dowall D (2009) Geochemistry of hypabyssal kimberlites from Lac de Gras, Canada: Comparisons to a global database and applications to the parent magma problem. Lithos 112: 236-248

Mitchell RH (1995) Kimberlites, orangeites, and related rocks. Plenum Press, New York

Rogers AJ, Hough TG, Davidson JM (2013) KX36 - rediscovering the diamond exploration potential of the central Kalahari in Botswana. The Journal of The Southern African Institute of Mining and Metallurgy 113: 539-545

Smith CB, Gurney JJ, Skinner EMW, Clement CR, Ebrahim N (1985) Geochemical character of Southern African kimberlites: A new approach based on isotopic constraints. Transactions of the Geological Society of South Africa 88: 267-280

Tappe S, Foley SF, Kjarsgaard BA, Romer RL, Heaman LM, Stracke A, Jenner GA (2008) Between carbonatite and lamproite: Diamondiferous Torngat ultramafic lamprophyres formed by carbonatefluxed melting of cratonic MARID-type metasomes. Geochim Cosmochim Acta 72: 3258-3286

Tappe S, Romer RL, Stracke A, Steenfelt A, Smart KA, Muehlenbachs K, Torsvik TH (2017) Sources and mobility of carbonate melts beneath cratons, with implications for deep carbon cycling, metasomatism and rift initiation. Earth and Planetary Science Letters 466: 152-167 